\title{
Hemangioma of Lower Lip - A Case Report
}

\author{
Muhammad Jailani \\ Plastic, Reconstructive and Aesthetic Surgery Division, Faculty of Medicine, Universitas Syiah Kuala, \\ Banda Aceh, Indonesia \\ jailani@unsyiah.ac.id
}

\begin{abstract}
Hemangioma is an endothelial tumor that most commonly found in infants and children. Most hemangiomas arise during birth or shortly after birth and proliferate during the first 18 months and then disappear spontaneously at the age of 5-10 years. The most complaints of patients with a hemangioma are the psychosocial problems, which are conditions that can affect the appearance and invite the attention of people around them. Some hemangiomas still require therapy, namely if the size and growth result in severe deformities, or if it interferes with vital functions, such as breathing, vision, hearing and digestion. Therapy depends on the size, location, and clinical stage. In this paper, we report an enormous hemangioma case involving the lower lip in male patients aged 45 years who has acquired wide excision (Cheiloplasty reduction).
\end{abstract}

Keywords: hemangioma; lips; tumor; excision

\section{Introduction}

Hemangioma is a benign tumor or hemartoma that occurs due to interference with the development and formation of blood vessels and can occur in all organs such as the liver, spleen, brain, bones, and skin.1 Hemangioma is a benign tumor of blood vessels that can be Occurs in al organs of the body and occurs most frequently in the head and neck area. ${ }^{2,3}$

There are two major vascular abnormalities, which are vascular tumors and malformations. The vascular tumor is an endothelial tumor with an increase in the proliferation of endothelial cells. 4 Hemangioma is a benign tumor of the blood vessels where angiogenesis becomes the basis of the growth of local capillary vessels. ${ }^{5}$ The terminology of Hemangiomas is an A time that continues to grow with endothelial hyperplasia during the proliferation phase and then undergoes a resolution phase. Whe vascular malformation is a celular lesion is notdynamic. ${ }^{6}$

A birthmark commonly found in infants is vascular abnormalities on the skin that can occur anywhere with a flat or prominent surface, and varying colors such as redness or purplish. This birthmark usually appears at the age of the first year of birth and then disappears with age. The birthmark was named Angioma in the mid-19th century, although the naming is still confusing because of the varying forms, colors, and lesions. ${ }^{7}$ Hemangioma is an endothelial tumor most commonly found in infants and children. ${ }^{4}$ Most hemangiomas arise at birth or shortly after birth and proliferate during the first 18 months and then disappear spontaneously at the age of $5-10$ years. ${ }^{8}$

Hemangiomas occur in $2.6 \%$ of birth in the world.9 Hemangiomas are often found in infants and children but do not close the possibility that can occur in adults. About 4-10\% of hemangiomas occur in Caucasian infants with a prevalence of 3-5 times higher in female infants. ${ }^{4}$ the incidence of Hemangiomas is also mentioned to be directly related to low birth weight. Hemangiomas can occur in premature infants weighing 1500-2000 grams and its prevalence may increase to $20 \%$ in infants premature $<1000$ grams. ${ }^{7,} 10$ the area of the lesion hemangioma most common is in the area of craniofacial $(60 \%) \%$ ) followed by the trunk area $(25 \%)$ and extremities $(15 \%)$. A hemangioma can occur only in one area of lesions (80\%) And the rest as multiple lesions (20\%). ${ }^{4}$ 
The most common complaints of patients with a hemangioma are psychosocial problems, which are conditions that can affect appearance and invite attention to the people around them. ${ }^{11}$ Some hemangiomas still require therapy, namely if the size and growth result in severe deformities, or if it interferes with vital functions, such as breathing, vision, hearing and digestion. ${ }^{12}$

\section{Case Report}

A patient, male, 45 years old came to the polyclinic plastic surgery at Dr. Zainoel Abidin hospital in Banda Aceh with complaints of a lump on the right lower lip. The patient claimed the lump began to appear at birth but with a very small size, bluish red color and does not interfere with patient activity. However, when the patient is 18 years old, the lump on the patient's lips is traumatized until bloody is stunted when the patient is playing soccer, then by the patient, the bleeding is compressed with ice, and then a few days later the appear bumps are getting bigger. The patient had already performed 2 times of surgery for this complaint, which was on 15 and 9 years ago. There is no family history suffers from similar illnesses.

In the clinical examination, the patient's general condition is within normal limits. In an extraoral examination, precisely on the part of the lips look asymmetric on the right side of the face, the patient also seems difficult to close his mouth. In the intraoral examination, there is mass on the right lower lip with a size of $5 \mathrm{~cm} \times 3.5 \mathrm{~cm} \times 3 \mathrm{~cm}$, bluish red color, compressible, painless, bruit, and thrill were not obtained (Fig. 1).

The result of blood laboratory test showed $\mathrm{Hb} 15.5 \mathrm{~g} / \mathrm{dl}$; Leukocytes 6.6/uL; Platelets $371 / \mathrm{uL} ;$ BUN/SK 17/1.03 $\mathrm{mg} / \mathrm{dl} ; \mathrm{Na} / \mathrm{K} / \mu$. The results of the chest radiograph are within normal limits. Patients then diagnosed as hemangioma of the lower lip. In these sufferers are done wide excision as a primary therapy due to attention to patient aesthetics.

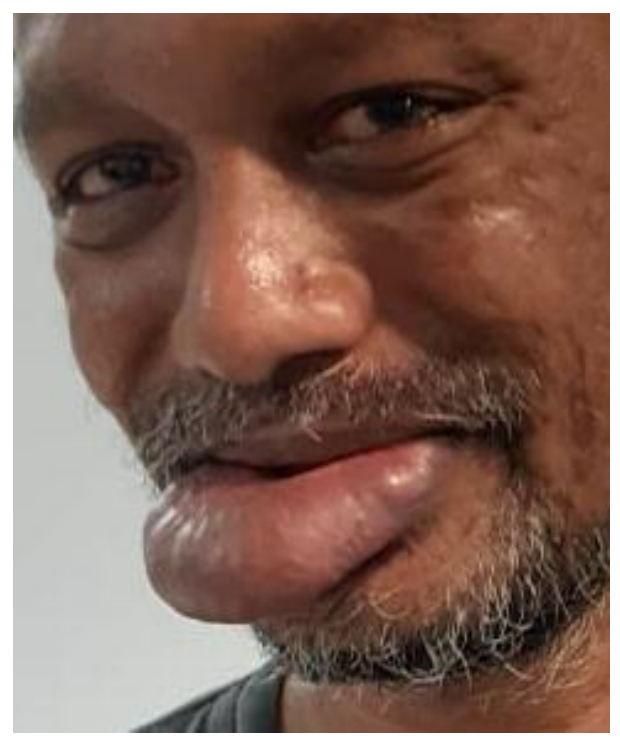

Figure 1. Preoperative Photo 


\section{Research Methods}

The surgery was carried out under general anesthesia in hospital. The marking was madewith surgical skin marker.Excision is made at the boundary of the swelling area, which starts from the vermilion of lower lip to the orbicularis oris muscle and then to the mentalis muscle.Excess amount isexcised both intraoral \& extraoral (Fig. 2). The entire mass of swelling was excised completely to prevent reoccurrence. Full-thicknesslip excision is used to ensure a smoothlip contour by avoiding bunching of the deeperlayers.

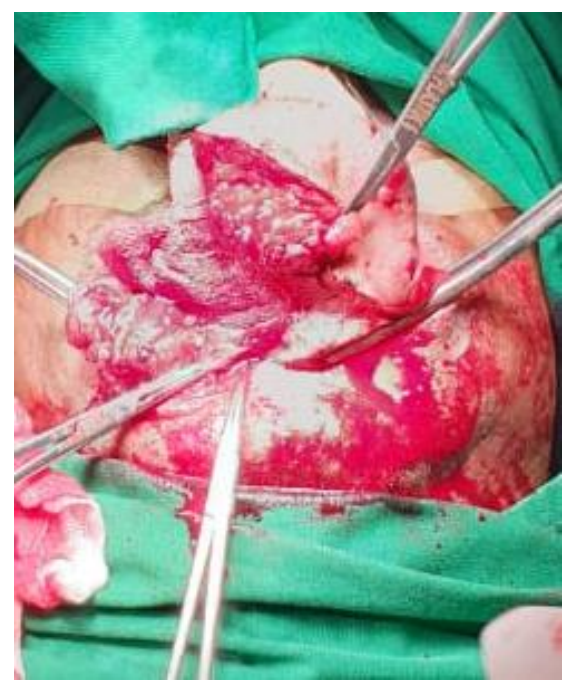

Figure 2. Excess Tissue Excised

Then the closure of thewedge excision is performed by suturing the muscles using absorbable suture and suturing the skin using non-absorbable suture (Fig. 3). The closure of a wedge excision of the lip canresult in an increase in vertical lip length. This can elevate the vermilion-cutaneous border. To avoid this, amore rectangular block excision of the hemangiomais preferred to a V-shaped excision, becauseclosure by flap advancement is less likely to lengthenthe vertical height of the lipalong the labial-mental crease. Excised tissue was sent to a laboratory for further investigation, and was confirmed to be a hemangioma. 3 days after treatment,healing wasuneventful without necrosis or infection, muscle function returnedimmediately after disappearance of edema, lipmovements were restored tonormal(Fig. 4). 14 days after treatment, the esthetic result wasremarkable (Fig. 5).

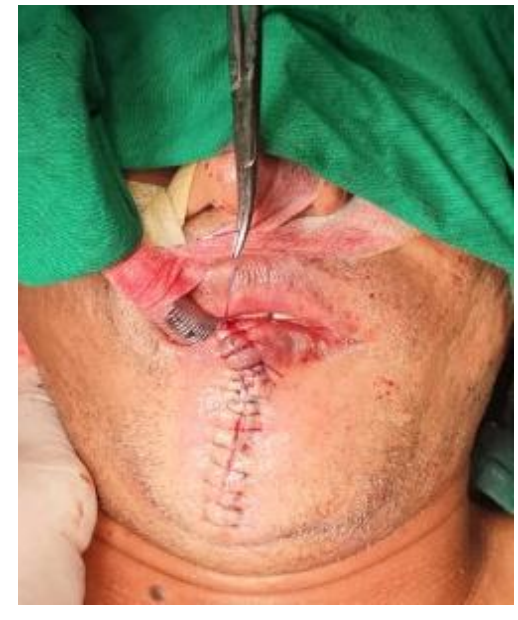

Figure 3. Postoperative Photo

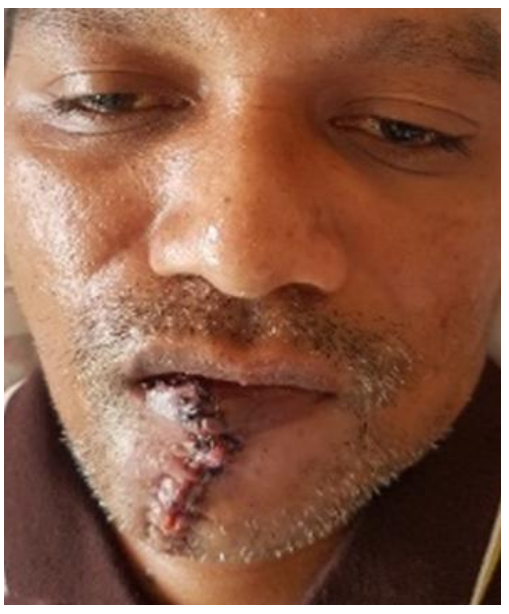

Figure 4. Days Postoperative

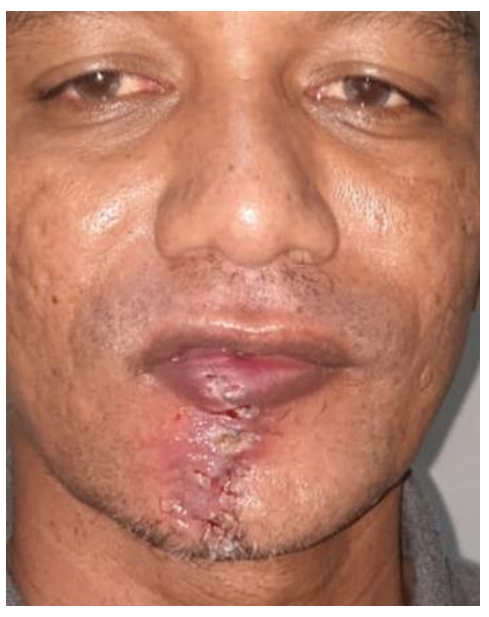

Figure. 5-14 days Postoperative 


\section{Discussion}

A patient, male, 45 years old came to the polyclinic plastic surgery at Dr. Zainoel Abidin hospital in Banda Aceh with complaints of a lump on the right lower lip. The lump began to appear at birth and enlarged after the trauma of the patient's lips which then causes bleeding in the lips of the patient and subsequently became an increasingly enlarged lump of the day. The patient then examined and then the diagnosis is made on the patient as hemangioma of the lower lip. The International Society for the Study of Vascular Anomalies classifies vascular abnormalities into 2 groups of vascular tumors and vascular malformations. ${ }^{13}$

Tumors are lesions originating from endothelial proliferation, whereas malformations are abnormalities of the structure with normal endothelial growth. ${ }^{13}$ vascular tumors are endothelial tumors with an increase in the proliferation of endothelial cells. ${ }^{4}$ Hemangioma is a benign tumor of the blood vessel where angiogenesis is the basis of the local growth of capillary vessels. ${ }^{5}$ Hemangioma Terminology is a time that continues to grow with endothelial hyperplasia during the proliferation phase and then experiencing The resolution phase. Whereas vascular malformations are lesions that are cellular, not dynamic. ${ }^{6}$

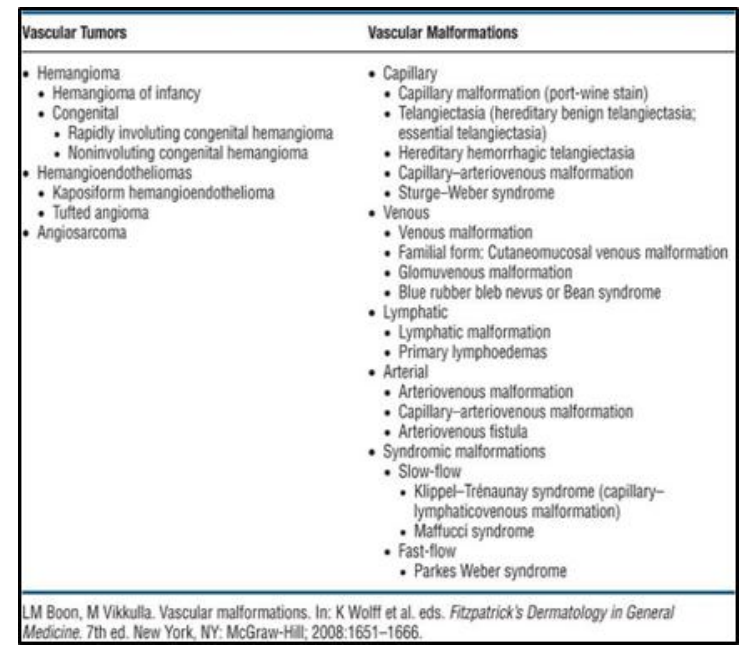

Figure 6. Classification of Vascular AbnormalitiesThe International Society for The Study of Vascular Anomalies. ${ }^{13}$

Hemangiomas show increased endothelial proliferation in the first year of birth, then can undergo involution and spontaneous regression. While the vascular malformations consist of dysplastic blood vessels with normal endothelial cycles. Vascular malformations never experience involution or regression. ${ }^{10}$ 


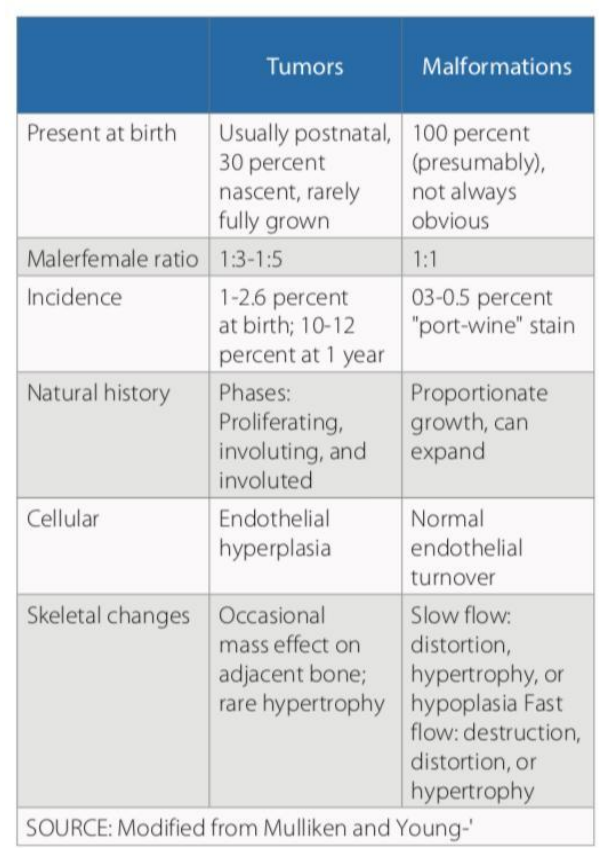

Figure 7. The Difference between Hemangioma and Vascular Malformation. ${ }^{14}$

A hemangioma can be divided into two groups, namely infantile and congenital hemangiomas. Infantile hemangiomas are more frequent and usually have been seen since birth and growing rapidly in a few months later, and stop growing after one year of age until involution occurs. Infantyl hemangiomas are generally divided into the phase of proliferation (0-1 years), the involution phase (1-5 years) and the cured phase (5-10 years). Congenital hemangiomas grow completely after birth and can occur involution or nonivolusion (permanently). ${ }^{15-17}$ Hemangioma pathogenesis is not known with certainty. It is thought that hemangiomas occur due to disorders of the angiogenesis and vasculogenesis processes causing uncontrolled proliferation of vascular elements. Vasculogenesis is the process of the occurrence of endothelial cell precursors into blood vessels, while angiogenesis is the development of new blood vessels from the existing blood vessel system.. ${ }^{18}$

Histopathology of hemangioma is divided into 2 types, namely capillary hemangiomas and Kavernosa hemangiomas. ${ }^{3}$ The diagnosis of Hemangiomas is made by anamnesis, physical examination, and radiology. A definite diagnosis can also be performed with histopathology inspection. 2,19

The clinical features of hemangiomas vary greatly depending on tumor size, location, depth, and clinical stage. ${ }^{20}$ The earliest sign of a hemangioma is the appearance of purple on the affected skin. ${ }^{18}$ Hemangiomas are rarely painless unless there is ulceration. ${ }^{15,21,22}$ almost in all cases, diagnosis can be made exclusively based on physical examinations and history. However, some types of hemangiomas can be confused with vascular malformations or other types of tumors, so that the following investigations are needed:

\section{USG}

Ultrasonography is useful for distinguishing hemangiomas from deep or subcutaneous dermis structures, such as cysts or lymph nodes. Ultrasound in general has limitations in evaluating the size and spread of hemangiomas. It also said that doppler ultrasound (2 $\mathrm{kHz}$ ) can be used for high blood vessel density and changes in arterial peaks. Examination using this tool is a sensitive and specific examination to identify an infantile hemangioma and distinguish it from other soft tissue masses. ${ }^{23}$ 


\section{MRI}

MRI is the imaging modality of choice because it is able to find out the location and spread of both cutaneous hemangiomas and extractions. MRI can also help differentiate hemangiomas that are proliferating from other high-flow vascular lesions (e.g. arteriovenous malformations). ${ }^{24-26}$

3. Skin Biopsy

Biopsy is needed if there is doubt in diagnosis or to rule out kaposiform hemangioendothelioma or malignant disease. Immunohistochemical examination can help make the diagnosis. ${ }^{18,20}$

Generally, hemangiomas do not cause complications and can be observed until spontaneous involution. Spontaneous regression occurred in $80 \%$ to $85 \%$ of cases there were 9 years of age. ${ }^{27,} 28$ although it's benign, psychologically hemangiomas are also quite influential to the patients and families, so it is often a question of when the spontaneous involution period will occur. Experts recommend that immediate treatment of hemangiomas $>10 \mathrm{~cm}$ in size because it is likely to occur giant hemangiomas. ${ }^{18}$ Some hemangiomas may be life-threatening or organ functions and certainly require immediate treatment. The treatment is performed on hemangiomas that can cause functional complications, which could cause permanent form changes, which are located in a place that interferes with cosmetics, causing psychosocial distress. ${ }^{29}$

Doing observation and consultation on plastic surgeons is also very important if the lesions are large, grow fast, have ulceration and even bleeding occurs, on the site of the lesion that could potentially snag, the presence of airway obstruction, interference vision, cardiovascular-related, thrombocytopenia occurs, pain and other possible complications. ${ }^{4,10,}$ 30 five percent of skin hemangiomas that are mostly in the lip and anogenital area, can undergo ulceration. Healing from re-epithelization takes a longer time. ${ }^{7}$

The indications for excision surgery are as follows: ${ }^{31}$

1. Hemangiomas that grow progressively.

2. Hemangiomas that have recurrent infections.

3. Hemangiomas whose surface reverberates, so it is feared accompanied by malignancy.

4. Cosmetically disrupting.

5. Hemangiomas that fail with medical treatment.

6. Hemangioma stemmed.

Surgery requires attention to several things, especially the risk of intraoperative and post-operative bleeding, as well as the involvement of important organs, such as the eye or facial nerve, the most important surgery must also consider the aspects of efficacy, efficiency, aesthetics and functional. 


\section{Conclusion}

Hemangioma is a benign tumor or hamartoma that occurs due to a disruption in the development and formation of blood vessels and can occur in all organs such as liver, spleen, brain bones and skin. This disease is often found in infants and children, but does not rule out the possibility of it can occur in adults. Hemangiomas are benign endothelial vascular tumors that are characterized by a typical growth phase consisting of a proliferation phase and an involution phase. Spontaneously, hemangiomas generally experience an involution phase and do not require treatment. However, in some cases spontaneous involution may occur or involution occurs slowly so that the size of the hemangioma still looks large.In severe cases and already very disturbing both functionally and aesthetically it is necessary to consider surgery or surgery. Surgery on hemangiomas should be done as early as possible to reduce the risk of tissue damage due to an enlarged tumor.

\section{References}

1. Hamzah, M. 2009. Hemangioma, dalam Ilmu Penyakit Kulit dan Kelamin, Balai Penerbit FK UI, Edisi Ketiga, Jakarta, 220-22.

2. Noviati, RS., Rosein, A. Hemangioma Kavernosa Hidung dan Sinus Paranasal. Dalam Kumpulan Naskah Konas XII Perhati, Semarang 28-30 Oktober 1999, hal 114-45.

3. Maves, MD. 1998. Hemangioma. In: Otolaryngology Head and Neck Surgery. Bailey BJ, editors, Vol II $2^{\text {nd }}$ ed. Philadelphia: Lippincot-Raven, p. 1817-9, 2817-32.

4. Marlel, JJ., Muliken, JB. 2005. Current Management of Hemangioma and Vascular Malformations. Clin Plastic Surgery, 32:99-116.

5. William, EF. et al. 2002. Haemangioma in Infant and Children: an Algoritma for Intervention. Arch Facial Plastic Surgery, 2:103-111.

6. Rosen, RJ., and Cotran. 2010. Pathologic of Vascular Surgery. New York $2^{\text {nd }}$ ed., pp.581-588.

7. Mulliken, JB., Vascular Anomalies. In: Aston, SJ., Beasle, RW., Thorne, CH, editors. 2007. Grabb and Smith's Plastic Surgery. $6^{\text {th }}$ ed. Philadelphia: Lippincott-Raven, p. 191-5.

8. Hall, GW., Magss, PHBB., Hann, IM. 2000. Kasabach-Merritt Syndrome: Caveats of Diagnosis and Management. Current Paediatrics, 10 :72-7 8.

9. Brenner, S. 2002. Some Considerations on Hemangioma. Skin med (I):47-49.

10. Sudjatmiko, G. 2010. Hemangioma. In: Petunjuk Praktis Ilmu Bedah Plastik Rekonstruksi. $2^{\text {nd }}$ ed. Jakarta: Yayasan Khazanah Kebajikan.

11. Greene, MD. 2002. Capillary Hemangioma. Am Academy Dermatology Journal, 42: 809-813

12. Odom, RB., James, WD., Berger, T. 2003. Andrew's Disease of The Skin. Clinical Dermatology, $9^{\text {th }}$ ed. Philadelphia: WB Saunders.

13. Boon, LM., Vikkulla, M. 2008. Vascular Malformations. In:K Wolff et al, editors. Fitzpatrick's Dermatology in General Medicine, $7^{\text {th }}$ ed. New York, NY: McGraw-Hill.

14. Mulliken, JB. Vascular Anomalies and Tumors of Skin and Subcutaneous Tissues. In: Fitzpatrick's Dermatology in General Medicine, $7^{\text {th }}$ ed. New York, NY: McGraw-Hill, $1651-1666$

15. Dourmishev, LA., Dourmishev, AL. 2005. Carniofacial Cavernous Hemangioma: Successful Treatment with Methylprednisolone. Acta Drematoven APA, 2(14) :49-52

16. Sadan, N., Wolach, B. 1996. Treatment of Hemangiomas of Infant with High Doses Prednisone. Jurnal Pediatri, 128: 141-6. 
17. Sarihan, H. et al. 1997. a New Treatment with Bleomycin for Complication Cutaneous Hemangioma in Children. Eur Jour Pediatric Surgery, 7 (3): 158-62.

18. Frieden, IJ. et al. 2005. Infantile Hemangiomas:Current Knowledge, Future Directions. Proceeding of a Research Workshop on Infantile Hemangiomas. Peditaric Dermatology, 22(5): 383-406.

19. Fierek, O. 2004. Large Intraosseous Hemangioma of The Temporal Bone in a Child. The Annals of Otology, Rhinology \& Laryngology May 2004, 113.5 ProQuest Medical Library, p.394-8.

20. Bruckner, AL., Frieden, IJ. 2006. Infantile Hemangioma. J Am Acad Dermatology, 55:671-82.

21. England, RJ. et al. 2006. Pediatric Pancreatic Hemangioma: A Case Report an Literature Review, J Pancreas, 7(5): 496-501.

22. Adam, S., Kirk, TR. 2005. Corticosteroid Treatment of Preorbital Hemangioma of Infancy: a Review of the Evidence. Br Journal Ophthalmology, 89: 1134-8

23. Dubois, J., et al. 1998. Soft Tissue Hemangioma of Infant and Children: Diagnosis Using Doppler Sonography, Am J Roengenol, 171:247-52.

24. Douri, T. 2003. Segmental Facial Hemangioma Accompanied by Brain Anomalies. DOJ, 9 (5): 22.

25. Bowman, RJC., Nischal, KK., Harper, JI. 2004. An Ultrasound Based Classification of Periocular Hemangiomas. Br Journal Ophthalmology, 88: 1419-21.

26. Khurana, KK., Mortelliti, AJ. 2001. The Role of Fine-Needle Aspiration Biopsy in the Diagnosis and Management of Juvenile Hemangioma of Parotid Gland and Cheek. Arch Pathol Lab Med, 125: 1340-43.

27. Jalil, S., Akhtar, J., Ahmed, S. 2006. Corticosteroids Therapy in the Management of Infantile Cutaneous Hemangiomas. JCPSP, 16(10): 662-5.

28. Ranchold, TM., Frieden, IJ., Fredrick, DR. 2005. Corticosteroids Treatment of Periorbital Hemangioma of Infancy: a Review of the Evidence. $\mathrm{Br}$ Journal Ophthalmology, 89: 1134-8.

29. Gontijo, B., Silva, CMR., Pereira, LB. 2005. Hemangioma of Infancy. Dermatologia, 78(6).

30. Ronchese, F. The Spontaneous Infolution of Cutaneous Vascular Tumors. Amer Journal Surgery, 86(4): 376-86.

31. Chan, YC., Giam, YC. 2005. Guidelines of Care for Cutaneous Hemangiomas. Ann Acad Med Singapore, 34:117-23. 